\title{
Correction to: Co-Creation of a Lanreotide Autogel/ Depot Syringe for the Treatment of Acromegaly and Neuroendocrine Tumours Through Collaborative Human Factor Studies
}

\author{
Daphne T. Adelman (D) - Dirk Van Genechten • Clémentine M. Megret • \\ Xuan-Mai T. Truong Thanh · Philippa Hand · Wendy A. Martin
}

Published online: January 18, 2020

(C) The Author(s) 2020

Correction to: Adv Ther (2019) 36:3409-3423

https://doi.org/10.1007/s12325-019-01112-3

In the Original Article, there is an error in the "participants" section of Results. The correct sentence is "A total of 213 participants took part in the studies, including 34 patients with acromegaly and 28 patients with NETs".

There is one more correction in the "Formative Studies: Development of the New Syringe" section of Results. The correct sentence is "Nevertheless, needle gauge and length (approximately 18 gauge needle $/ 20 \mathrm{~mm}$ ) were retained from the previous lanreotide autogel/ depot syringe, as reducing needle gauge and

The original article can be found online at https://doi. org/10.1007/s12325-019-01112-3.

D. T. Adelman $(\bowtie)$

Feinberg School of Medicine, Northwestern

University, Chicago, IL, USA

e-mail: d-adelman@northwestern.edu

D. Van Genechten

International Neuroendocrine Cancer Alliance

(INCA), Boston, USA

D. Van Genechten

Belgian Neuroendocrine Tumour (NET) and

Multiple Endocrine Neoplasia (MEN) Association,

Blankenberge, Belgium

length could increase injection force and risk of injection failure to reach the deep subcutaneous tissue".

Open Access. This article is licensed under a Creative Commons Attribution-NonCommercial 4.0 International License, which permits any non-commercial use, sharing, adaptation, distribution and reproduction in any medium or format, as long as you give appropriate credit to the original author(s) and the source, provide a link to the Creative Commons licence, and indicate if changes were made. The images or other third party material in this article are

C. M. Megret

Ipsen PharmSciences, Dreux, France

X.-M. T. Truong Thanh

Ipsen Pharma, Boulogne-Billancourt, France

P. Hand

London North West University Healthcare NHS

Trust, London, UK

W. A. Martin

King's College Hospital, London, UK 
included in the article's Creative Commons licence, unless indicated otherwise in a credit line to the material. If material is not included in the article's Creative Commons licence and your intended use is not permitted by statutory regulation or exceeds the permitted use, you will need to obtain permission directly from the copyright holder. To view a copy of this licence, visit http://creativecommons.org/licenses/by$\mathrm{nc} / 4.0 /$. 